\title{
Formulation of Indigenous Rhizobacterial Isolates from Healthy Soybean's Root, which Ability to Promote Growth and Yield of Soybean
}

\author{
Trimurti Habazar ${ }^{\# 1}$, Yulmira Yanti ${ }^{\#}$, Cahaya Ritonga ${ }^{\#}$ \\ \# Agroecology Department, Andalas University, Padang, West Sumatera, Indonesia \\ E-mail: ${ }^{1}$ xtrimurtihabazar@yahoo.com
}

\begin{abstract}
Plant growth promoting rhizobacteria are a group of bacteria, that actively colonize plant roots, induce the resistance of plant to pathogen, increase plant growth and yield. Our previous research had showed, that one of rhizobacterial isolates from soybean root effective to promote growth and yield of soybean. To maintain the effectivity of this bacterial isolate during storage, transportation and application, so need to be formulated. The aim of this research was to get the best carrier for formulation to maintain the effectivity of rhizobacterial isolate in storage to promote growth and yield of soybean. This research have used random complete design with 16 treatments and 3 replicates. The treatments were combination of material carrier for formulation of rhizobacterial isolate (peat soil, tapioca flour and coconut water $+1 \%$ palm oil) and time of storage of formula $(0,1,3,5$ and 7 weeks) and control. The parameter were population density of rhizobacterial isolate on formula, growth development (germination rate, plant height, number of leaves and twigs) generative phase (time of flowering and pod) and yield (weight of seed) of soybean. The results showed that all formulas of rhizobacterial isolate able to increase growth and yield of soybean. The best combination which effective to increase growth and yield of soybean were rizobacteria in peat soil formula and storage for five weeks.
\end{abstract}

Keywords - Rhizobacteria, formulation, soybean, biofertilizer.

\section{INTRODUCTION}

Soybean represent a crop with major economic value, pesticides and organic fertilizers are commonly applied before sowing and during vegetation period with negative impact on environment. Fertilization is considered as one of the main sources of environmental pollution caused by agriculture. When high fertilizer rates are applied, nutrient losses take place which pollute agricultural ecosystems. Defense strategies were developed in order to minimize the environmental burden caused by agricultural pollution. There is growing interest in the use of biological approaches to replace chemicals in fertilizing soils or improving plant resistance against phytopathogens. One of these strategies is based on the usage of biofertilizers-microorganisms isolated from soil that can stimulate plant growth [2].

Considering the benefits of intensive agriculture in our time and the negative impact of chemical fertilizers and pesticides against the environment, usage of plant growthpromoting rhizobacteria (PGPR) like biofertilizers is one of the most promising biotechnologies used for increasing the primary production, eliminating the need of chemical fertilizers [2]. Use of plant growth promoting microbes as biocontrol agents and biofertilizers give eco-friendly and inexpensive alternatives to the use of chemicals.

There are several ways in which plant growth promoting bacteria can directly facilitate plant growth. They may fix atmospheric nitrogen and supply it to plants usually a minor component of the benefit that the bacterium provides to the plant; synthesize siderophores which can sequester iron from the soil and provide it to plant cells which can take up the bacterial siderophore-iron complex; synthesize phytohormones such as auxins, cytokinins and gibberelins, which can act to enhance various stages of plant growth; solubilize minerals such as phosphorus, making them more readily available for plant growth; and synthesize the enzyme 1-aminocyclopropane carboxylate (ACC) deaminase, which can lower plant ethylene levels ([3], [4], [5]).

Phosphate solubilizing bacteria (PSB) are the group of common PGPR in rhizosphere. Secretion of organic acids and phosphatases to solubilize insoluble phosphate to soluble forms are common in this group [6]. Although several phosphate solubilizing bacteria occur in soil, their numbers are not adequate to compete with other bacteria commonly established in the rhizosphere [3]. Moreover, the population of inorganic $\mathrm{P}$-solubilizing microorganism is very 
low, less than $10^{2} \mathrm{cfu}$ g-1 of soil. Therefore the number of PSM is more important in the rhizosphere than in nonrhizosphere soil [7].

We have found two rhizobacterial isolates, which have the ability to increase growth and yield of soybean [8]. It is necessary to pack such bacteria in inert materials which can also be packaged and stored. Initially, it is essential to determine whether the bacteria can survive in the bioformulations for a reasonable period of time and whether they can induce similar effects to those observed by live bacterial cells [9]. Commercial application of PGPR for control of soil-borne diseases depends upon the development of commercial formulations in which bacteria can survive for a considerable length of time, on the development of a suitable method of application to control pathogen establishment and disease development, and assessment of their efficacy under field conditions [10]. The efficacy of bacterial inoculants would largely depend on the type of formulation and delivery technology [11].

In search of efficient PGPR strains with multiple activities, prepared eight bioformulations using two strains of Pseudomonas fluorescens isolated from different rhizosphere soils and plant roots in the Iranian cotton fields. Formulations included a talc-based powder and bentonitebased powder as mineral carriers and peat and rice bran as organic carriers for increasing stability in interaction between PGPR and cotton plants [12]. Bioformulations of the bacterium in saw dust, rice husk and tea waste were found to survive for more than 9 months in vitro with populations in the range of $1 \times 10^{6-7}$ c.f.u $/ \mathrm{ml}$. The bioformulations were as effective as aqueous suspensions in plant growth promotion. There was no significant difference among the aqueous suspension or different bioformulations in increase in height and number of leaves after 2 months of application, indicating that the application of bioformulations could also effectively promote tea plant growth [9].

The present investigation was undertaken to study the efficacy of PGPR formulations along with solid and broth carriers on soybean in greenhouse conditions.

\section{MATERIAL AND METHODS}

\section{A. Microbial culture}

The bacteria studied, rhizobacterial isolates PL4Rz1.1, were screened in previous in vitro and in planta experiments for their plant growth promoting traits, i.e. production of indoleacetic acid (IAA), increase growth and yield of soybean. They were obtained from healthy soybean rhizosphere in Pesisir Selatan District, West Sumatera Province, Indonesia.

Bacterial cultures were routinely maintained on NA medium and were sub-cultured twice a month.

\section{B. Preparation of solid and broth carriers.}

Powdered tapioca (TP), powdered organic compounds of peat $(\mathrm{PT})$ and coconut water + palm oil $(\mathrm{CW})$ were chosen as carriers. They were steamsterilized at $140 \mathrm{kPa}$ for $30 \mathrm{~min}$, and for solid carrers dried aseptically in glass trays for $12 \mathrm{~h}$ at $50^{\circ} \mathrm{C}$ before use.

C. Preparation of bacterial suspensions.
The rhizobacterial cells were harvested after two days of growth in NA medium, centrifuged at $6,000 \mathrm{rpm}$ for $15 \mathrm{~min}$ and resuspended in phosphate buffer $(0.01 \mathrm{M}, \mathrm{pH} 7.0)$. The concentration was adjusted with a spectrophotometer to approximately $10^{8} \mathrm{CFU} \mathrm{ml}-1$ and used as inoculum [13]. The bacterial strains were kept at $-80^{\circ} \mathrm{C}$ in $44 \%$ glycerol and cells from stocks were first grown on NA medium to verify their purity. The inoculum was produced by transferring one loopful from the culture to $100 \mathrm{ml}$ of $\mathrm{NB}$ in a $250 \mathrm{ml}$ Erlenmeyer flask and incubating at room temperature $(28 \pm$ $2^{\circ} \mathrm{C}$ ) on a shaker at $150 \mathrm{rpm}$ for $48 \mathrm{~h}$ (preculture). For mainculture was produced by transferring $1 \mathrm{ml}$ from preculture to $50 \mathrm{ml}$ of coconut water in a $250 \mathrm{ml}$ flask and incubating at the same manner as preculture. After $48 \mathrm{~h}$ incubation, the broth containing $9 \times 10^{8} \mathrm{CFU} \mathrm{ml}^{-1}$

\section{Development of TP-based, PT-based, and CW-based formulations of rhizobacterial strains.}

To $100 \mathrm{ml}$ bacterial suspension, a mixture of $1 \mathrm{~kg}$ of a purified tapioca flour (TP) or peat (PT) powder, $50 \mathrm{~g}$ sucrose was added under sterile conditions. The product was shadedried to reduce the moisture content (less than 20\%), then packed in polypropylene bags and sealed. To $100 \mathrm{ml}$ bacterial suspension, a mixture of 11 of a sterilized cocnut water $(\mathrm{CW})$ was added under sterile conditions. Those formulas were incubated for $0,1,3,5$ and 7 weeks at room temperature.

\section{E. Host.}

Seeds of soybean cv. Willis were obtained from the Bogor Agricultural University, Bogor, West Java Indonesia. Germination tests were carried out by the paper towel method [14]. PGPR-treated seeds and controls were seeded onto paper towels. The brown germination paper was soaked in distilled water. Thirty seeds of soybean were placed equidistantly on the paper. Another presoaked paper towel was placed on the first one so that the seeds were held in position. The towels were then rolled and wrapped with polythene to prevent drying. After incubation for 7 days, the towels were unrolled and the number of seeds germinated were counted. Seed emergence was analyzed at the end of 7 days of incubation by the method of [15]. The experiment was carried out with four replicates of 30 seeds each.

\section{E. Seed and soil treatment.}

PGPR formulations were used as seed treatments, soil Amendments. For seed treatment, the seeds were initially surface-sterilized with $1 \%$ sodium hypochlorite and soaked in a double volume of sterile distilled water containing the mentioned formulations ( $10 \mathrm{~g} \mathrm{~kg}^{-1}$ of seed). After $12 \mathrm{~h}$, the bacterial suspension was drained off and the seeds were dried under shade for $30 \mathrm{~min}$ and planted [16]. For soil amendment, the formulations were mixed with the potting $\operatorname{mix}$ in the ratio $1: 40(\mathrm{v} / \mathrm{v})[12]$.

\section{F. Effect of PGPR formulations on growth promotion of soybean under greenhouse}

For the evaluation of growth promotion under greenhouse conditions there were 16 treatments $(1$ Treatment $=$ without rhizobacteria), the three PGPR formulations were applied after $0,1,3,5,7$ weeks incubation periode. Seeds were sown 
in 30x40 $\mathrm{cm}$ polybag filled with $5 \mathrm{~kg}$ autoclaved soil and manure at the ratio of $3: 1$. Each treatment (formulation, incubation periode) consisted of five replicates and a single seed per pot. For seed treatment method seeds treated with distilled water served as control that did not receive the formulations served as control. Treatments were arranged in a randomized complete design. Plants were maintained at $25-30{ }^{\circ} \mathrm{C}$ with $95 \%$ relative humidity. Plants were watered daily, and no artificial fertilization was used. Plant height was measured from the base to the tip of the plant, number of leaves per plant were recorded until 60 days after seeding (DAS).

Statistical analyses. The experiment included 17 treatments each with 4 replicates. All data were analyzed by analysis of variance (ANOVA). Means were compared using Duncan Multiple Range Test (DNMRT) $(\mathrm{p}=0.05)$, by the SPSS statistical package.

\section{RESULT AND DISCUSSION}

\section{A. Result}

The viability of the bacterium in formulations was tested during the storage period of 7 weeks at two weeks interval. Results revealed that the rhizobacterial isolate was viable till 7 weeks of storage; this isolate could survive in the range of $1 \times 10^{6}$ c.f.u $/ \mathrm{ml}$ in bioformulations of saw dust, rice husk and $1 \times 10^{7}$ c.f.u/ml in tea waste respectively (Table 1 ).

TABLE I

GROWTH OF RIZHOBACTERIAL ISOLATES IN FORMULATIONS AT DIFFERENT PERIODS OF INCUBATION (CFU/G OR ML)

\begin{tabular}{|l|c|c|c|c|c|}
\hline \multirow{2}{*}{$\begin{array}{c}\text { Formu- } \\
\text { lation }\end{array}$} & \multicolumn{5}{|c|}{ Incubarion periode (weeks) } \\
\cline { 2 - 6 } & $\mathbf{0}$ & $\mathbf{1}$ & $\mathbf{3}$ & $\mathbf{5}$ & $\mathbf{7}$ \\
\hline Peat & $3,8 \times 10^{8}$ & $2,5 \times 10^{8}$ & $1,7 \times 10^{8}$ & $1,5 \times 10^{8}$ & $1,4 \times 10^{8}$ \\
\hline $\begin{array}{l}\text { Tapioca } \\
\text { flour }\end{array}$ & $1,6 \times 10^{8}$ & $1,2 \times 10^{8}$ & $1,0 \times 10^{8}$ & $1,0 \times 10^{8}$ & $0,9 \times 10^{8}$ \\
\hline $\begin{array}{l}\text { Coconut } \\
\text { water+ } \\
\text { palm oil }\end{array}$ & $1,6 \times 10^{8}$ & $1,5 \times 10^{8}$ & $1,4 \times 10^{8}$ & $1,3 \times 10^{8}$ & $0,9 \times 10^{8}$ \\
\hline
\end{tabular}

In general, all the formulations tested increased growth parameters under greenhouse conditions. However, the degree-of-growth promotion varied among formulations and incubation periodes. Application of rhizobacteria in formulations of tapioca flour, peat and coconut water led to significant increase in seed emergence of soybean (Table 2). In comparison with the nontreated control, all the formulations of PGPR except for peat formulation with 1 week incubation periode, significantly enhanced seed germination. The rate of enhancement varied with the formulations used. The highest enhancement rate of germination was obtained with the formulations three weeks incubated tapioca flour, three weeks incubated peat, three weeks incubated coconut water+palm oil, 0 week incubated tapioca flout and 0 week incubated peat, which recorded 100 $\%$ and $88,89 \%$ germination and a $125,02 \%$ and $100,02 \%$ effectifity, respectively, compared to the control with 44,44 $\%$ germination (Figure 1).

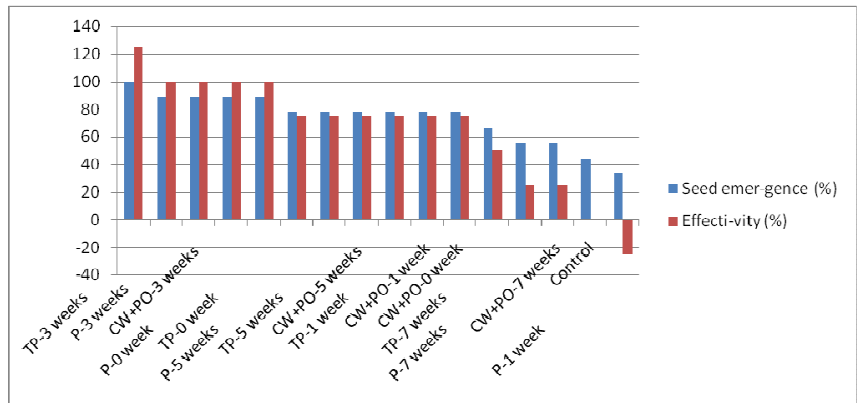

Fig. 1. Seed emergence of rhizobacterial formula introduced soybean and their effectivity to increase seed emergence.

The growth was measured in terms of increase in height of soybean two months after application. Statistical analysis revealed initial height was insignificant among the treatments but three weeks after rhizobacterial application in three weeks incubated tapioca flour, three weeks incubated peat and without incubated coconut, significant results were observed. In case of increase in height after 2 months of application, different formulations though all of them were significantly higher than control (Fig. 2 and 3).

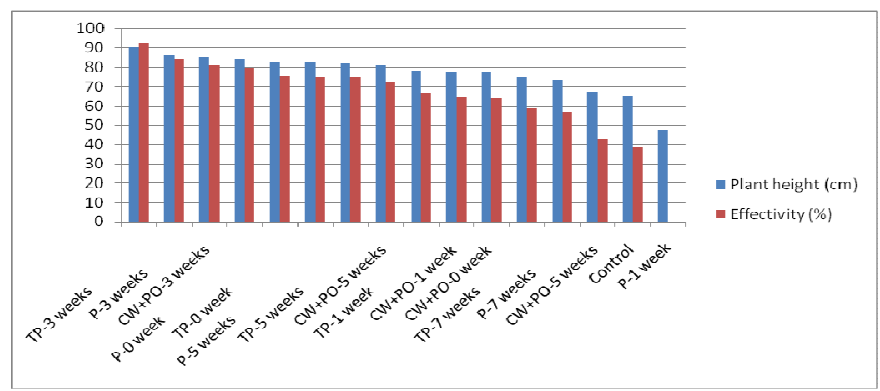

Fig. 2. Plant height of rhizobacterial introduced soybean and their effectivity. Absis $=$ Rhizobacterial formula and incubation periode.

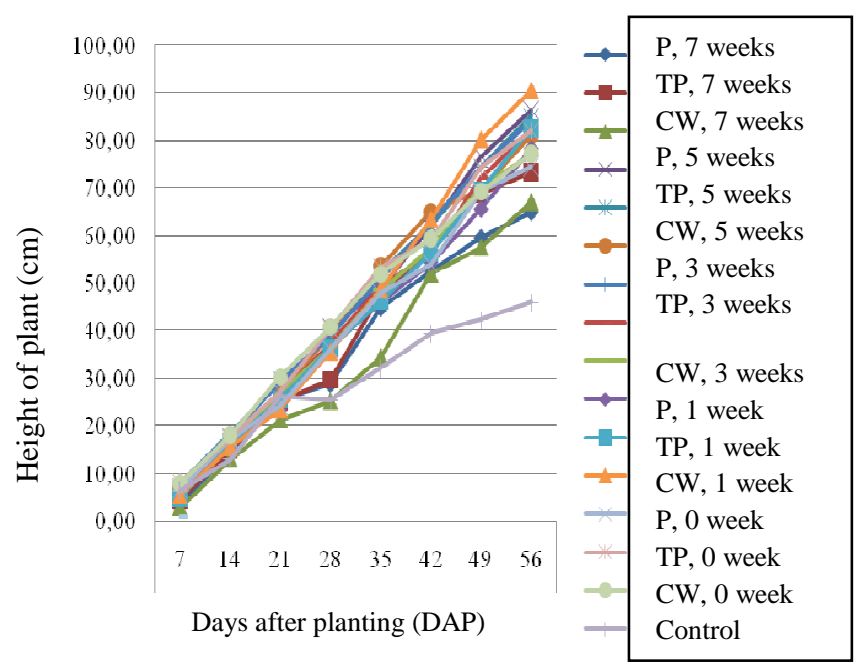

Fig. 3. Development of plant height on rhizobacterial introduced soybean

In case of increase in number of leaves after 2 months of application, there was significant difference among the different formulations and incubation periodes. All of them were significantly higher than control (Figure 4). Statistical analysis revealed initial leaf numbers were insignificant among the treatments but in without incubated tapioca flour, 
one and five weeks incubated peat and 5 weeks incubated tapioca flour significant results were observed.

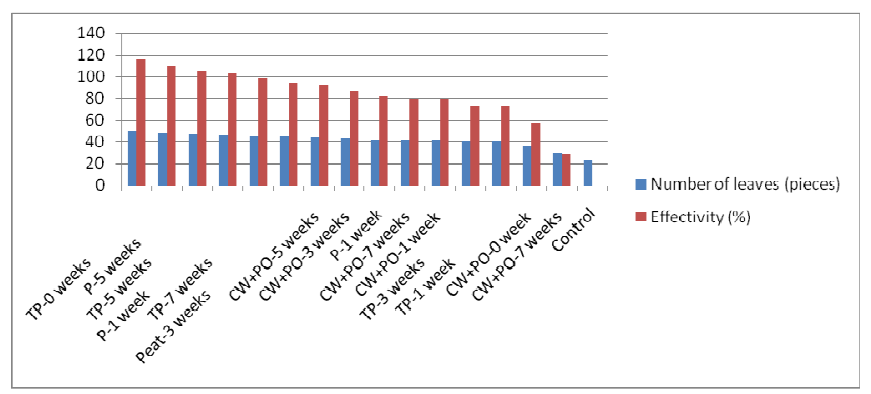

Fig. 4. Number of leaves on rhizobacterial introduced soybean and their effectivity

The days required by plants to reach flowering was significantly advanced by seven days faster in rhizobacterial introduced soybean compare than control, such as three, five and seven weeks incubated coconut water formula, thre, five and seven weeks incubated tapioca flour formula, and one, three, and seven weeks incubated peat formula (Table 2).

TABLE II

BEGIN OF FLOWERINGE PHASE OF RHIZOBACTERIAL INTRODUCED SOYBEAN AND THEIR EFFECTIVITY

\begin{tabular}{|l|r|r|}
\hline \multicolumn{1}{|c|}{$\begin{array}{c}\text { Formulation- } \\
\text { Incubation periode } \\
\text { (weeks) }\end{array}$} & $\begin{array}{c}\text { Generative } \\
\text { phase } \\
\text { (DAP) }\end{array}$ & $\begin{array}{l}\text { Effectivity } \\
(\%)\end{array}$ \\
\hline $\begin{array}{l}\text { Coconut water+palm oil 0 } \\
\text { week }\end{array}$ & 47,67 & $-3,63$ \\
\hline Control & 46,00 & 0,00 \\
\hline Tapioca flour-1 weeks & 44,67 & 2,89 \\
\hline Peat-5 weeks & 44,00 & 4,35 \\
\hline $\begin{array}{l}\text { Coconut water+palm oil-1 } \\
\text { weeks }\end{array}$ & 43,33 & 5,80 \\
\hline Peat-0 week & 43,33 & 5,80 \\
\hline Peat-1 week & 41,00 & 10,87 \\
\hline Peat-7 weeks & 40,33 & 12,33 \\
\hline $\begin{array}{l}\text { Coconut water+palm oil - } \\
\text { 7 weeks }\end{array}$ & 40,00 & 13,04 \\
\hline Tapioca flour-0 week & 40,00 & 13,04 \\
\hline $\begin{array}{l}\text { Coconut water+palm oil - } \\
\text { 5 weeks }\end{array}$ & 40,00 & 13,04 \\
\hline Tapioca flour -5 weeks & 39,33 & 14,50 \\
\hline Tapioca flour -3 weeks & 39,33 & 14,50 \\
\hline Peat-3 weeks & 39,33 & 14,50 \\
\hline Tapioca flour -7 weeks & 39,33 & 14,50 \\
\hline $\begin{array}{l}\text { Coconut water+palm oil 3 } \\
\text { week }\end{array}$ & 39,00 & 15,22 \\
\hline SD = 9,69 \% & & \\
\hline
\end{tabular}

Under greenhouse conditions the soybean yield was significantly increased by fast all the formulations and incubation periode compared with the nontreated control. In case of increase in soybean yield, there was significant difference among the different formulations and incubation periodes. All of them were significantly higher than control (Figure 5).

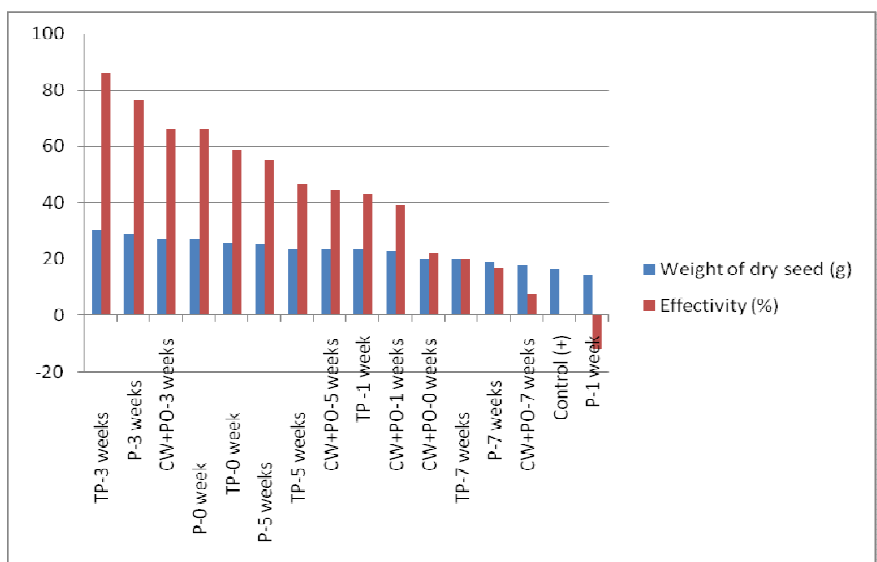

Fig. 5. Soybean yield after application of rhizobacterial formula and different incubation periode and their effectivity.

\section{B. Discussion}

We The ability of PGPR in growth promotion and resistance induction in various crops is well documented ([17], [18], [19], [20]). The results reported here corroborate earlier studies and indicate a future possibility that PGPR formulations can be used to promote growth of crop plants. Treatments with rhizobacterial formulations significantly enhanced the growth of soybean plants.

Peat formulations have also promoted growth in different plants like cucumber, watermelon, squash, ornamentals, vegetables, pepper, tobacco and tree species like loblolly pine, and lodge pine Douglas fir. ([21], [22], [23], [24], [25], [26], [27]). However, this is the first report that demonstrates the efficiency of tapioca flour and coconut water formulations promoted growth in soybean plant.

Our results suggest that PGPR formulation can be used practically in production of soybean. The practical applications of these formulations were supported by the magnitude of growth promotion recorded by these treatments which was highly significant in comparison with the nontreated control. The most important result was the considerable increase in yield of soybean. Another important result was the advancement of flowering faster by 7-8 days than non treated control.

Earlier studies on PGPR have also reported that rhizobacteria are potential growth enhancers in different. crops like potato, pearl millet, and sorghum ([28], [29], [30]). In the present study, all the formulations tested showed their efficacy in enhancing germination of soybean. The treated plants showed advanced emergence of seedlings in comparison to the control. In general, all the formulations showed a significant enhancement of growth and reproductive parameters such as height, number of leaf, flowering stage, and yield od soybean under greenhouse conditions 


\section{CONCLUSIONS}

All the formulations showed a significant enhancement of growth and reproductive parameters such as height, number of leaf, flowering stage, and yield of soybean under greenhouse conditions.

\section{ACKNOWLEDGMENT}

This research was funded by DP2M-DIKTI DEPDIKNAS (Hibah Kompetensi grant), Contract Nr. 134/UN16/PL/2011, April 21, 2012. We would like to sincerely thanks to Director of DP2M-DIKTI.

\section{REFERENCES}

[1] M. Stefan, S. Dunca, Z. Olteanu, L. Oprica, E. Ungureanu, L. Hritcu, M. Mihasan \& D. Cojocaru. Soybean (Glycine max [L] Merr.) inoculation with Bacillus punilus RS3 promotes plant growth and increases seed protein yield: relevance for environmentally-friendly agricultural applications. Carpathian Journal of Earth and Environmental Sciences, Vol. 5, No. 1, p. 131 - 138, April 2010.

[2] M. Stefan, M. Mihasan, L. Raus, D. Topa, S. Dunca.. Agriculture applications of some rhizobacterial starins isolated from Moldavian Plaine Cambic-Chernozemic soils. Lucrări Ştiinţifice -Vol. 51:191196, seria Agronomie, 2009.

[3] B. R. Glick. The enhancement of plant growth by free living bacteria. Can J Microbiol 41: 109-114, 1995.

[4] B. R. Glick, Z. Cheng, J. Czarny and J. Duan, Promotion of plant growth by ACC deaminase containing soil bacteria. Eur. J. Plant Pathol., 119: 329-339, 2007b.

[5] B. R. Glick, B. Todorovic, J. Czarny, Z. Cheng, J. Duan and B. McConkey, 2007a. Promotion of plant growth by bacterial ACC deaminase. Crit. Rev. Plant Sci., 26: 227-242, 2007a.

[6] H. Antoun, and J. W. Kloepper, Plant Growth Promoting Rhizobacteria. Encyclopedia of Genetics. London: Academic Press, 2001.

[7] R. M. N. Kucey, H. H. Janzen, and M. E. Leggett, Microbiologically Mediated Increases in Plant-Available Phosphorus. Advances in Agronomy, 42, 199-228, 1989.

[8] Y. Yanti, T. Habazar, Z. Resti and D. Suhalita, Penapisan isolat rizobakteri dari perakaran tanaman kedelai yang sehat untuk pengendalian penyakit pustul bakteri (Xanthomonas axonopodis pv. glycines). J. HPT Tropika 13(1):24-34, 2013

[9] U. Chakraborty, B. N. Chakraborty and A. P. Chakraborty, Induction of plant growth promotion in Camellia sinensis by Bacillus megaterium and its bioformulations. World Journal of Agricultural Sciences 8 (1): 104-112. ISSN 1817-3047, 2012.

[10] S. Nakkeeran, K. Kavitha, G. Chandrasekar, P. Renukadevi, and W. G. D. Fernando, Induction of plant defence compounds by Pseudomonas chlororaphis PA23 and Bacillus subtilis BSCBE4 in controlling damping-off of hot pepper caused by Pythium aphanidermatum. Biocontrol Science and Technology; 16(4): 403416, 2006

[11] R. D. Lumsden, J. A. Lewis and D. R. Fravel, Formulation and delivery of bio-control agents for use against soil-borne plant pathogens. In: F.R. Hall Formulation and Delivery, Washington, DC, USA, American Chemical Society, pp: 166-182, 1995.

[12] S. S. Ardakani, A. Heydari, N. Khorasani and R. Arjmandi, Development of new bioformulations of Pseudomonas fluorescens and evaluation of these products against damping-off of cotton seedlings. Journal of Plant Pathology 92 (1), 83-88, 2010.
[13] D. C. Thompson, Evaluation of bacteria immunization: an alternative to pesticides for control of plant disease in greenhouse and field. In: Bay-Petersen J. (ed.). The Biological Control of Plant Disease, pp. 30-40. Fertilizer Technology Centre, Taiwan, 1996.

[14] ISTA, Proceedings of the international Seed Testing Association, International Rules for Seed Testing. Seed Sci. Technol. 21, pp. 2530. 1993.

[15] A. A. Abdul Baki and J. D. Anderson, Vigor determination in soybean seed by multiple criteria. Crop Sci. 13, 630-633, 1973.

[16] P. VidhyasekaranP, R. Rabindran, M. Muthamilan, K. Nayar, K. Rajappan, N. Subramanian, K. Vasumathi, Development of a powder formulation of Pseudomonas flourescens for control of rice blast. Plant Pathology 46:291-297, 1997.

[17] L. C. van Loon, P. A. H. M. Baker, and C. M. J. Pieterse, Systemic resistance induced by rhizosphere bacteria. Annu Rev Phytopathol 36:453-483, 1998

[18] E. A. Barka, A. Belarbi, C. Hachet, J. Nowak, J. Audran, Enhancement of in vitro growth and resistance to gray mold of Vitis vinifera co-cultured with plant growth-promoting rhizobacteria. FEMS Microbiol. Lett. 186, 91-95, 2000.

[19] S. Burdman, E. Turkevitch, and Y. Okon, Recent advances in the use of plant growth promoting rhizobacteria (PGPR) in agriculture. In: Subba Rao, N.S., Dommergues, Y.R. (Eds.), Microbial Interaction in Agriculture and Forestry. Vol. 2., Science Publishers Inc, Enfield (NH), USA, pp. 229-249, 2000.

[20] V. Ramamoorthy, R. Viswanathan, T. Raguchander, V. Prakasam, R. Samiyappan, Induction of systemic resistance by plant growth promoting rhizobacteria in crop plants against pests and diseases. Crop Protection 20:1-11, 2001.

[21] M. S. Reddy, R. Rodriguez-Kabana, D. S. Kenney, C. M. Ryu, S Zhang, Z. Yan,N. Martinez-Ochoa, J. W. Kloepper, Growth promotion and induced systemic resistance (ISR) mediated by a biological preparation. Phytopathology 89, S65, 1999.

[22] D. S. Kenney, M. S. Reddy, J. W. Kloepper, Commercial potential of biological preparations for vegetable transplants. Phytopathology 89, S39. 1999.

[23] J. W. Kloepper, R. Rodriguez-Kabana, D. S. Kenney, M. S. Reddy, N. Martinez-Ochoa, N. Kokalis-Burelle, K. Arthur, Development of an integrated biological approach to develop transplants suppressive to various plant diseases. Phytopathology 89, S40, 1999.

[24] N. Martinez-Ochoa, N. Kokalis-Burelle, R. Rodriguez-Kabana, J. W. Kloepper, Use of organic amendments, botanical aromatics, and rhizobacteria to induce suppressiveness of tomato to the root-knot nematode, Meloidogyne incognita. Phytopathology 89, S49, 1999.

[25] C. M. Ryu, M. S. Reddy, S. Zhang, J. F. Murphy, J.W. Kloepper, 1999. Plant growth promotion of tomato by a biological preparation (LS 213) and evaluation for protection against cucumber mosaic virus. Phytopathology 89, S87. ev and V. P. Veiko, Laser Assisted Microtechnology, 2nd ed., R. M. Osgood, Jr., Ed. Berlin, Germany: Springer-Verlag, 1998.

[26] Z. Yan, M. S. Reddy, Q.Wang, R. Mei, J. W. Kloepper, Role of rhizobacteria in tomato early blight control. Phytopathology 89, S87, 1999.

[27] S. Zhang, M. S. Reddy, C. M.. Ryu, J. W. Kloepper, Relationship between in vitro and in vivo testing of PGPR for induced systemic resistance against tobacco blue mold. Phytopathology 89, S89, 1999.

[28] G. Lazarovitz, and J. Nowak, Rhizobacteria for improvement of plant growth and establishment. Hort. Sci. 32, 92-96, 1997.

[29] S. Umesha, S. M. Dharmesh, S. A. Shetty, M. Krishnappa, H. S. Shetty, Biocontrol of downy mildeu disease of pear millet using Pseudomonas fluorescens. Crop Prot. 17, 387-392, 1999.

[30] N. S. Raju, S. R. Niranjana, G. R. Janaradhana, H. S. Prakash, H. S. Shetty, S. B. Mathur, Improvement of seed quality and field emergence of Fusarium moniliforme infected sorghum seeds using biological agents. J. Sci. Food Agri. 79, 206-212, 1999. 